\title{
Rapid Bioassessment of Magura haor (Floodplain wetland), Cachar District, Assam, India using Aquatic Insects
}

\author{
ARPITA DALAL and SUSMITA GUPTA* \\ Department of Ecology and Environmental Science, Assam University, Silchar-788011, India.
}

http://dx.doi.org/10.12944/CWE.10.1.37

(Received: December 22, 2014; Accepted: February 02, 2015)

\begin{abstract}
Investigation on the water quality of the floodplain wetland, Magura through rapid assessment survey using aquatic insects for the four seasons were done during 2013-14. Aquatic insects were collected from the two sites and were identified up to family level. All together 5 orders (Hemiptera, Coleoptera, Odonata, Ephemeroptera and Diptera) and 21 families were recorded from the wetland. 17 families from site 1 (Hemiptera- 7 families, Coleoptera- 4 families, Odonata- 3 families, Ephemeroptera- 1 family and Diptera- 2 families) and 18 families from site 2 (Hemiptera- 6 families, Coleoptera- 6 families, Odonata- 2 families, Ephemeroptera- 1 family and Diptera- 3 families) were recorded. Four family level biotic indices- SIGNAL 2, ASPT, BMWP and FBI were used to determine the status of the water quality. According to SIGNAL 2 and BMWP scores it was moderately polluted, whereas ASPT showed doubtful quality but FBI proved very good (site 1) and good water condition (site 2). This study revealed that only one biotic index cannot give proper justification of the water quality status of a wetland.
\end{abstract}

Key words: Rapid bioassessment, Aquatic insects, haor, Cachar.

\section{INTRODUCTION}

Rapid bioassessment survey is the quick and easy method of analyzing water quality of any water body by using benthic macroinvertebrates. Benthic macroinvertebrates are common inhabitants of freshwater systems and are also sensitive elements of aquatic biota ${ }^{1}$. Therefore, changes in its taxonomic richness and composition are considered sensitive tools for perceiving alterations in aquatic ecosystems ${ }^{2}$. Therefore, rapid procedures for assessing the biotic communities of surface waters become widely used in recent years where they allow large number of sites to examine at a low $\cos ^{3}$. In general, rapid bioassessment can be defined as an evaluation of the condition of a water body using biological surveys and other direct measurements of the resident biota in surface waters ${ }^{4}$. Resident biota in water body are natural monitors of environmental quality and can reveal the effects of episodic as well as cumulative pollution and habitat alteration ${ }^{5}$. Biotic indices such as Trent Biotic index ${ }^{6}$; BMWP score ${ }^{7}$, ASPT score ${ }^{7}$, Wisconsin Biotic Index (BI) and Family Biotic Index (FBI) for macro-invertebrates are used to detect and monitor water quality and human perturbations in varying ecosystems like streams ${ }^{8}$, rivers $^{9}$ and lakes ${ }^{10}$.

The present study is focused on one floodplain wetland (locally called as 'haor') named Magura in Cachar district of Assam, India. This study is aimed to establish ecological status of the wetland and classify the sampling sites with the help of different biotic indices where aquatic insects have been used as bioindicator. 


\section{MATERIALS AND METHODS}

Cachar distict $\left(25.0833^{\circ} \mathrm{N}, 92.9167^{\circ} \mathrm{E}\right)$ is the commercial district of Barak valley. Magura haor ( $\mathrm{N} \mathrm{24}{ }^{0} 36.910^{\prime} \mathrm{E} \mathrm{092^{0 }}{ }^{2}$.924') is the floodplain wetland of River Rukni, one of the tributaries of River Barak. During monsoon its depth reached up to 150 $\mathrm{cm}$. It covers an area of $1,87,146$ sq. meters (Fig. 1 ). Major parts of the wetland get dried up during dry period and used for paddy cultivation and grazing of the cattles. The wetland is rich in macrophytes like Eichhornia crassipes, Ludwigia adscendens, Utricularia aurea, Pistia sp., Nymphoid indicum, and Myriophyllum spectrum.
Insect samples were collected seasonally during post-monsoon (2013) to monsoon (2014) from the two sites of the wetland- site 1 and site 2 in replicates. For the collection of aquatic insects "Kick method" was applied where vegetation was disturbed and a circular net (mesh size $60 \mu \mathrm{m}$ ) was dragged around the vegetation for a unit of time ${ }^{11-12}$. Three such drags constituted one sample ${ }^{13}$. Collected insects were immediately sorted and preserved in $70 \%$ ethyl alcohol. They were identified upto family level using Magnus stereozoom microscope with the help of standard keys ${ }^{14-20}$. Different biotic indices like SIGNAL, ASPT, BMWP and FBI were used for the rapid bioassessment survey of the Magura haor.

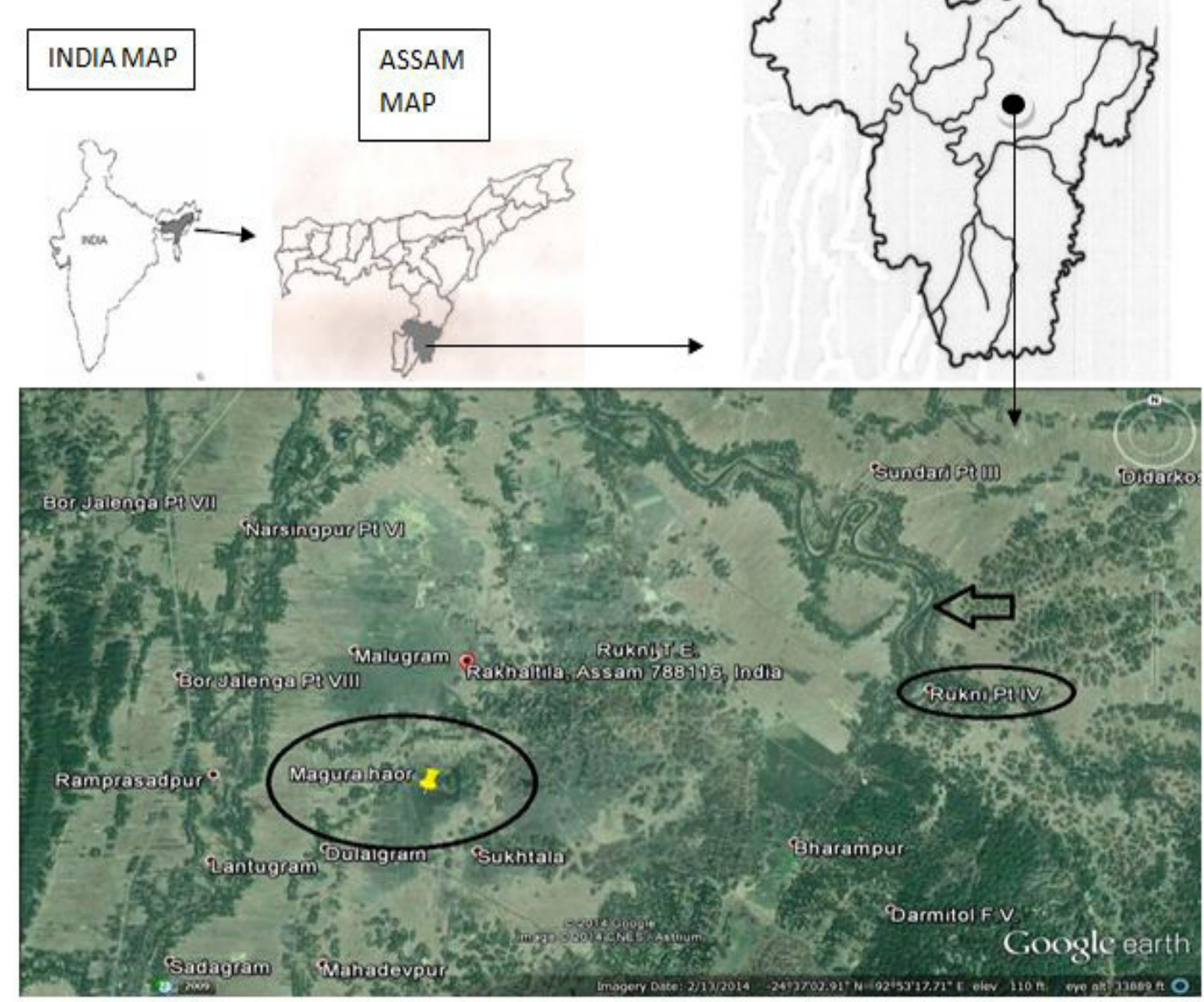

Fig. 1: Map of Cachar district, Assam showing Magura haor along with Rukni river. (source: Google map) 


\section{RESULTS AND DISCUSSION}

Study revealed 5 orders (Hemiptera, Coleoptera, Odonata, Ephemeroptera and Diptera) and 21 families from the wetland. 17 families had been recorded from site 1, they were- Gerridae, Corixidae, Notonectidae, Hydrometridae, Pleidae, Nepidae, Belostomatidae (Order Hemiptera), Noteridae, Hydrophilidae, Chrysomelidae, Dytiscidae (Order Coleoptera), Libellulidae, Coenagrionidae, Aeshnidae (Order Odonata), Baetidae (Order Ephemeroptera), Chironomidae and Culicidae (Order Diptera) and 18 families from site 2, they were- Gerridae, Corixidae, Notonectidae, Nepidae, Hydrometridae, Veliidae (Order Hemiptera), Noteridae, Hydrophilidae, Chrysomelidae, Dytiscidae, Hydraenidae, Hydrochidae (Order Coleoptera), Libellulidae, Coenagrionidae (Order Odonata), Baetidae (Order Ephemeroptera), Chironomidae, Culicidae and Tabanidae (Order Diptera).

Table 1 showed the SIGNAL 2 scores for site 1 and site 2 for the four seasons of Magura haor. The SIGNAL (Stream Invertebrate Grade Number-Average level) is a family level scoring system for macroinvertebrates sample where it gives the indication of water quality from where the sample was collected ${ }^{21}$. In site 1 , highest score was shown in monsoon while lowest score was shown in pre-monsoon. Although species richness was found more in pre-monsoon, monsoon season scored highest because of the presence of more relatively sensitive groups. In site 2, again monsoon season secured highest score and post monsoon season had lowest score. In both the sites, weight factor of Baetidae family was found highest which also has highest SIGNAL 2 sensitivity grade and highest relative abundance in monsoon season (Fig. 2), thus increasing its SIGNAL 2 score as a whole. Both the sites showed severe pollution status (i.e., < 4). Similar status of SIGNAL 2 score was also recorded from other floodplain wetlands of Cachar district22-23. Though it is mainly used in streams and rivers where organic pollution is less, it can also be applied in wetlands and other lentic ecosystems. But the scores would be less as some of the macroinvertebrate families that have the highest SIGNAL 2 sensitivity grades are naturally rare in wetlands ${ }^{21}$. Therefore we can consider this wetland under moderate water pollution.

Table 2 showed the BMWP and ASPT scores for site 1 and site 2 for the four seasons of Magura haor. BMWP (Biological Monitoring Working Party) is a family level scoring system which represents organisms' tolerance to pollution.

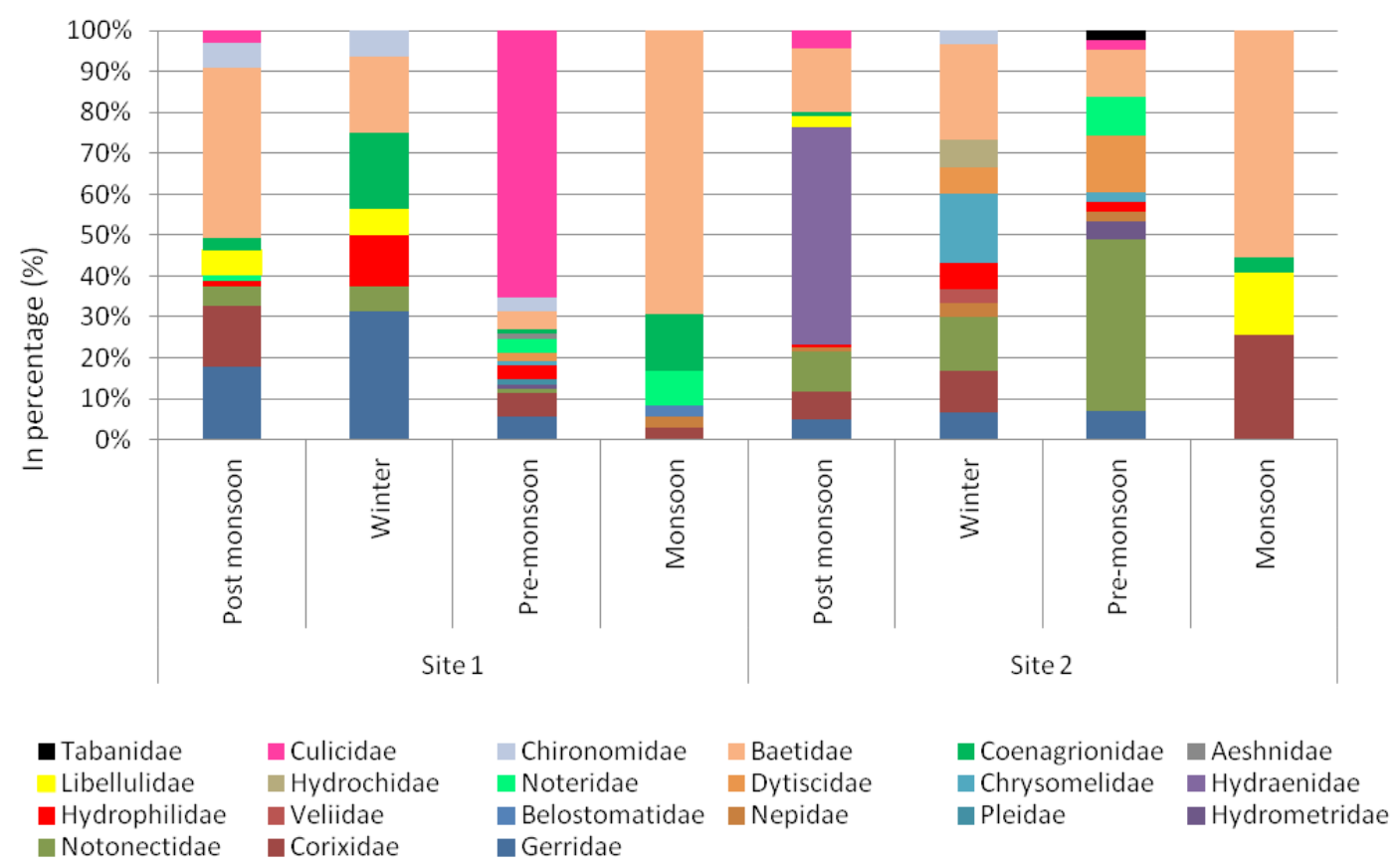

Fig. 2: Relative abundance graph of site 1 and site 2 of Magura haor for four seasons (2013-14) 
Table 1: Seasonal variation in SIGNAL 2 scores for site 1and site 2 of Magura haor

\begin{tabular}{|c|c|c|c|c|c|c|c|c|c|c|}
\hline \multirow[b]{2}{*}{ Sites } & \multirow[b]{2}{*}{$\begin{array}{l}\text { Invertebrate } \\
\text { families } \\
\text { collected }\end{array}$} & \multirow[b]{2}{*}{$\begin{array}{c}\text { SIGNAL 2 } \\
\text { Sensitivity } \\
\text { grade }\end{array}$} & \multicolumn{2}{|c|}{$\begin{array}{c}\text { Post- } \\
\text { monsoon }\end{array}$} & \multicolumn{2}{|c|}{ Winter } & \multicolumn{2}{|c|}{$\begin{array}{c}\text { Pre- } \\
\text { monsoon }\end{array}$} & \multicolumn{2}{|c|}{ Monsoon } \\
\hline & & & $\begin{array}{l}\text { Weight } \\
\text { factor }\end{array}$ & $\begin{array}{l}\text { Grade x } \\
\text { weight } \\
\text { factor }\end{array}$ & $\begin{array}{l}\text { Weight } \\
\text { factor }\end{array}$ & $\begin{array}{l}\text { Grade x } \\
\text { weight } \\
\text { factor }\end{array}$ & $\begin{array}{l}\text { Weight } \\
\text { factor }\end{array}$ & $\begin{array}{l}\text { Grade x } \\
\text { weight } \\
\text { factor }\end{array}$ & $\begin{array}{l}\text { Weight } \\
\text { factor }\end{array}$ & $\begin{array}{c}\text { Grade } x \\
\text { weight } \\
\text { factor }\end{array}$ \\
\hline \multirow[t]{19}{*}{ Site 1} & Gerridae & 4 & 4 & 16 & 2 & 8 & 2 & 8 & - & - \\
\hline & Corixidae & 2 & 3 & 6 & - & - & 2 & 4 & 1 & 2 \\
\hline & Notonectidae & 1 & 2 & 2 & 1 & 1 & 1 & 1 & - & - \\
\hline & Hydrometridae & 3 & - & - & - & - & 1 & 3 & - & - \\
\hline & Pleidae & 2 & - & - & - & - & 1 & 2 & - & - \\
\hline & Nepidae & 3 & - & - & - & - & - & - & 1 & 3 \\
\hline & Belostomatidae & 1 & - & - & - & - & - & - & 1 & 1 \\
\hline & Noteridae & 4 & 1 & 4 & - & - & 1 & 4 & 2 & 8 \\
\hline & Hydrophilidae & 2 & 1 & 2 & 1 & 2 & 2 & 4 & - & - \\
\hline & Chrysomelidae & 2 & - & - & - & - & 1 & 2 & - & - \\
\hline & Dytiscidae & 2 & - & - & - & - & 1 & 2 & - & - \\
\hline & Libellulidae & 4 & 2 & 8 & 1 & 4 & - & - & - & - \\
\hline & Coenagrionidae & 2 & 1 & 2 & 2 & 4 & 1 & 2 & 2 & 4 \\
\hline & Aeshnidae & 4 & - & - & - & - & 1 & 4 & - & - \\
\hline & Baetidae & 5 & 5 & 25 & 2 & 10 & 2 & 10 & 5 & 25 \\
\hline & Chironomidae & 3 & 2 & 6 & - & - & 1 & 3 & - & - \\
\hline & Culicidae & 1 & 1 & 1 & - & - & 5 & 5 & - & - \\
\hline & TOTAL & & 22 & 72 & 9 & 29 & 22 & 54 & 12 & 43 \\
\hline & SIGNAL SCORE & & 3.27 & 3.22 & 2.45 & 3.58 & & & & \\
\hline \multirow[t]{20}{*}{ Site 2} & Gerridae & 4 & 3 & 12 & 1 & 4 & 1 & 4 & - & - \\
\hline & Corixidae & 2 & 3 & 6 & 2 & 4 & - & - & 3 & 6 \\
\hline & Notonectidae & 1 & 4 & 4 & 2 & 2 & - & - & - & - \\
\hline & Nepidae & 3 & 1 & 3 & 1 & 3 & 1 & 3 & - & - \\
\hline & Hydrometridae & 3 & - & - & - & - & 1 & 3 & - & - \\
\hline & Veliidae & 3 & - & - & 1 & 3 & - & - & - & - \\
\hline & Hydrophilidae & 2 & 1 & 2 & 2 & 4 & 1 & 2 & - & - \\
\hline & Hydraenidae & 3 & 5 & 15 & - & - & - & - & - & - \\
\hline & Noteridae & 4 & - & - & 1 & 4 & 2 & 8 & - & - \\
\hline & Chrysomelidae & 2 & - & - & 2 & 4 & - & - & - & - \\
\hline & Dytiscidae & 2 & - & - & 1 & 2 & 3 & 6 & - & - \\
\hline & Hydrochidae & 4 & - & - & 1 & 4 & - & - & - & - \\
\hline & Libellulidae & 4 & 2 & 8 & - & - & - & - & 2 & 8 \\
\hline & Coenagrionidae & 2 & 1 & 2 & - & - & - & - & 1 & 2 \\
\hline & Baetidae & 5 & 4 & 20 & 3 & 15 & 2 & 10 & 4 & 20 \\
\hline & Culicidae & 1 & 2 & 2 & - & - & 2 & 2 & - & - \\
\hline & Chironomidae & 3 & - & - & 1 & 3 & - & - & - & - \\
\hline & Tabanidae & 3 & - & - & - & - & 1 & 3 & - & - \\
\hline & TOTAL & & 26 & 74 & 18 & 52 & 14 & 41 & 10 & 36 \\
\hline & SIGNAL SCORE & & 2.85 & 2.88 & 2.93 & 3.60 & & & & \\
\hline
\end{tabular}

N.B: signal score $=$ (total of grade $\mathrm{x}$ weight factor) $/$ total of weight factor; Signal 2 sensitivity grade $=1-10$, Signal 2 scores: healthy habitat $>6$, mild pollution 5-6, moderate pollution $4-5$, severe pollution $<4^{21-24}$. 
Table 2: Seasonal variation in BMWP and ASPT scores for site 1and site 2 of Magura haor

\begin{tabular}{|c|c|c|c|c|c|}
\hline \multirow[b]{2}{*}{ Sites } & \multirow[b]{2}{*}{$\begin{array}{l}\text { Invertebrate } \\
\text { families collected }\end{array}$} & \multicolumn{4}{|c|}{ BMWP SCORE } \\
\hline & & Post- monsoon & Winter & Pre- monsoon & Monsoon \\
\hline \multirow[t]{19}{*}{ Site 1} & Gerridae & 5 & 5 & 5 & - \\
\hline & Corixidae & 5 & - & 5 & 5 \\
\hline & Notonectidae & 5 & 5 & 5 & - \\
\hline & Hydrometridae & - & - & 5 & - \\
\hline & Pleidae & - & - & 5 & - \\
\hline & Nepidae & - & - & - & 5 \\
\hline & Belostomatidae & - & - & - & 5 \\
\hline & Noteridae & 5 & - & 5 & 5 \\
\hline & Hydrophilidae & - & 5 & 5 & - \\
\hline & Chrysomelidae & 5 & 5 & 5 & - \\
\hline & Dytiscidae & - & - & 5 & - \\
\hline & Libellulidae & - & 8 & - & - \\
\hline & Coenagrionidae & 6 & 6 & 6 & 6 \\
\hline & Aeshnidae & - & - & 8 & - \\
\hline & Baetidae & 4 & 4 & 4 & 4 \\
\hline & Chironomidae & 2 & - & 2 & - \\
\hline & Culicidae & 1 & - & 1 & - \\
\hline & TOTAL & 38 & 38 & 66 & 30 \\
\hline & ASPT SCORE & 4.22 & 5.42 & 4.71 & 5.00 \\
\hline \multirow[t]{20}{*}{ Site 2} & Gerridae & 5 & 5 & 5 & - \\
\hline & Corixidae & 5 & 5 & - & 5 \\
\hline & Notonectidae & 5 & 5 & - & - \\
\hline & Nepidae & 5 & 5 & 5 & - \\
\hline & Hydrometridae & - & - & 5 & - \\
\hline & Veliidae & - & 5 & - & - \\
\hline & Hydrophilidae & 5 & 5 & 5 & - \\
\hline & Hydraenidae & 5 & - & - & - \\
\hline & Noteridae & - & 5 & 5 & - \\
\hline & Chrysomelidae & - & 5 & - & - \\
\hline & Dytiscidae & - & 5 & 5 & - \\
\hline & Hydrochidae & - & 5 & - & - \\
\hline & Libellulidae & 8 & - & - & 8 \\
\hline & Coenagrionidae & 6 & - & - & 6 \\
\hline & Baetidae & 4 & 4 & 4 & 4 \\
\hline & Chironomidae & - & 2 & - & - \\
\hline & Culicidae & 1 & - & 1 & - \\
\hline & Tabanidae & - & - & 2 & - \\
\hline & TOTAL & 49 & 56 & 37 & 23 \\
\hline & ASPT SCORE & 4.9 & 4.66 & 4.11 & 5.75 \\
\hline
\end{tabular}

N.B: BMWP score $=0-10$ very poor, $11-40$ poor, $41-70$ moderate, $71-100$ good, $>100$ very good ; ASPT score $=$ total of BMWP score / total number of families represented; $>6$ clean water, 5-6 doubtful quality, 4-5 probable moderate pollution, $<4$ probable severe pollution ${ }^{25}$ 


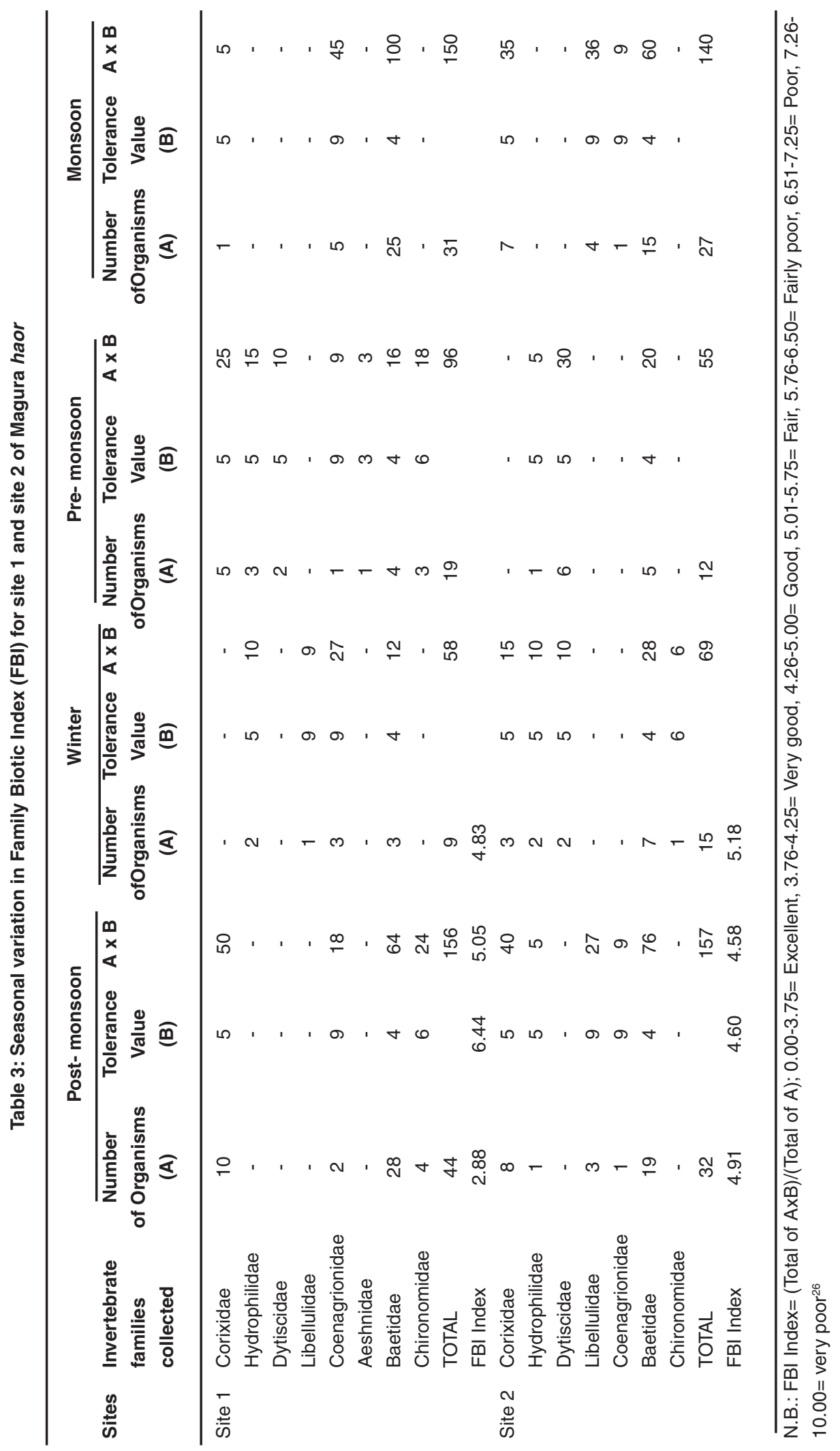


The greater their tolerance towards pollution, lower the BMWP score ${ }^{27}$. In site 1, BMWP score was found highest in pre-monsoon season and lowest in monsoon. The highest score reflected moderate condition of water according to BMWP grade. In site 2, winter had highest score and had moderate condition and monsoon had lowest score and had poor water condition. Overall we can say, according to BMWP score this wetland was moderately polluted. Similar studies at other parts of the world also revealed moderate pollution according to BMWP score $^{28-29}$. ASPT (Average Score Per Taxon) is also a family level scoring system for the average tolerance level of all the taxa within the community and was calculated by dividing the BMWP by the number of families represented in the sample ${ }^{30}$. In case of ASPT score, for site 1 winter season had highest score and in site 2 monsoon season had highest score. Both the highest scores came under doubtful quality. Previous studies also revealed doubtful quality for ASPT score 22-23.

Table 3 represented the Family Biotic Index (FBI) for site 1 and site 2 for the four seasons of Magura haor. $\mathrm{FBI}$ is a family biotic index which provides a single tolerance value which is the average of the tolerance values of all species within the benthic arthropod community. The Biotic Index was subsequently modified to the family-level with tolerance values ranging from 0 (very intolerant) to 10 (highly tolerant) based on their tolerance to organic pollution thus creating $\mathrm{FBI}^{26}$. $\mathrm{FBI}$ is different from the other two scores in the interpretation of tolerance status. In this lower the score more clean is the system. In site 1, post-monsoon season had the lowest score (2.88) and so it came under 'very good' condition and in site 2 pre-monsoon had lowest score (4.58) which had a 'good' water condition. Thus, both the sites represented less pollution condition according to $\mathrm{FBI}$.

Figure 2 showed relative abundance graph of the wetland of site 1 and site 2 . In site 1
Baetidae was found most abundant in Monsoon followed by Culicidae in Pre-monsoon whereas in site 2 most abundant families were Hydraenidae in Post-monsoon and Baetidae in Monsoon followed by Notonectidae in Pre-monsoon. Family Baetidae was recorded as most abundant family in both the sites of this wetland. Though the family Baetidae belongs to order Ephemeroptera which is a part of EPT sensitive group, occurrence of insects belonging to this family indicate moderate pollution condition of water ${ }^{31-33}$. During dry period intensive farming practices carried out by the inhabitants might have contributed to the deterioration of water quality. A study on aquatic insects of one oxbow lake of South Assam also revealed similar result ${ }^{34}$.

\section{CONCLUSION}

This study confirmed that rapid bioassessment survey can be a very useful tool in the determination of water quality of a system. Different biotic indices used in this study revealed that the system is moderately polluted although according to $\mathrm{FBI}$ it is in good or very good condition. We found that use of only one biotic index cannot give proper justification of the water quality of a system. There is need to analyze several indices which can lead to a conclusive remark. Therefore, it can be concluded that although the wetland had some impact of pollution, it is still under condition of reviving to its original state if intervention is made in time. The need of the hour is environmental awareness among the inhabitants regarding water quality and its possible consequences.

\section{ACKNOWLEDGEMENT}

The first author would like to thank the Head, Department of Ecology and Environmental Science, Assam University, Silchar for providing laboratory facilities and the funding agency, Department of Science and Technology (DST) INSPIRE fellowship for carrying out the Ph.D research work. 


\section{REFERENCES}

1. Alves M. A. S., Pimm S. L., Storni A., Raposo M. A., de M., Brooke L., Harris G., Foster A. and Jenkins C. N., Mapping and exploring the distribution of a threatened bird, Greywinged Cotinga, ORYX, 42(4): 562-566 (2008).

2. Mance G., Pollution Threat of Heavy Metals in Aquatic Environments, New York: Elsevier Applied Science, Barking (1987).

3. Rosenberg D. M. and Resh V., Freshwater Biomonitoring and Benthic Macroinvertebrates. Chapman \& Hall, New York-London. 486 p. (1993).

4. Barbour, M. T., Gerritsen J., Snyder B. D. and Stribling J.B., Rapid Bioassessment Protocols for Use in Streams and Wadeable Rivers: Periphyton, Benthic Macroinvertebrates and Fish, Second Edition, EPA 841-B-99-002. U.S. Environmental Protection Agency; Office of Water; Washington, D.C. (1999).

5. Barbour, M. T., Gerritsen J., Griffith G. E., Frydenborg R., McCarron E., White J. S. and Bastian M. L., A framework for biological criteria for Florida streams using benthic macroinvertebrates, Journal of the North American Benthological Society, 15(2): 185211 (1996).

6. Woodiwiss F. S., The biological system of stream classification used by the River Trent Board. Chem Ind, 14: 443-447 (1964).

7. Armitage P. D., Moss D., Wright J. F. and Furse M. T., The performance of a new biological water quality score system based on macroinvertebrates over a wide range of unpolluted running-water sites, Water Res, 17(3): 333-347 ( 1983).

8. Lenat D. R. and Crawford J. K., Effects of land use on water quality and aquatic biota of three North Carolina piedmont streams, Hydrobiol, 294(3): 185-200 (1994).

9. Chessman B. C., Growns I., Curreys J. and Plunket-Cole N., Predicting diatom communities at the genus level for the rapid biological assessment of rivers, Freshwater Biol, 41: 317-331 (1999).

10. Schartau A. K., Moe S. J., Sandin L., McFarland B. and Raddum G. G., Macroinvertebrate indicators of lake acidification: analysis of monitoring data from UK, Norway Sweden, Aquat Ecol, 42(2): 293-305 (2008).

11. Brittain J. E., Studies on the lentic Ephemeroptera and Plecoptera of Southern Norway, Norsk Entomologisk Tidsskrift, 21; 135-151 (1974).

12. Macan T.T and Maudsley R., The insects of the stony substratum of Windermere, Transaction of the Society for British Entomology, 18; 1-18 (1968).

13. Subramanian K. A. and Sivaramakrishnan K. G., Aquatic Insects for Biomonitoring Freshwater Ecosystems - A Methodology Manual.Asoka Trust for Research in Ecology and Environment (ATREE), Bangalore, India, 31 (2007).

14. Bal A. and Basu R. C., Insecta: Hemiptera: Mesovelidae, Hydrometridae, Veliidae and Gerridae. In: State fauna Series 3: Fauna of West Bengal. Part 5, Zoological Survey of India, Culcutta, 511-534 (1994a).

15. Bal A. and Basu R. C., Insecta: Hemiptera: Belostomatidae, Nepidae, Notonectidae and Pleidae. In: State fauna Series 3: Fauna of West Bengal. Part 5, Zoological Survey of India, Culcutta, 535-558 (1994b).

16. Bouchard R. W. Jr., Guide to Aquatic Invertebrates of the Upper Midwest. Water Resources Center, University of Minnesota, St. Paul, MN. 208. (2004).

17. Epler J. H., The Water Beetles of Floridaan identification manual for the families Chrysomelidae, Curculionidae, Dryopidae, Dytiscidae, Elmidae, Gyrinidae, Haliplidae, Helophoridae, Hydraenidae, Hydrochidae, Hydrophilidae, Noteridae, Psephenidae, Ptilodactylidae and Scir tidae, Florida Department of Environmental Protection, Tallahassee, FL. 399 + iv p (2010).

18. Kumar A., Descriptions of the last instar larvae of odonata from the Dehra Dun Valley (India), with notes on biology I (Suborder: Zygoptera), Oriental Insects, 7; 23- 61 (1973a).

19. Kumar A., Descriptions of the last instar larvae of Odonata from the Dehra Dun Valley 
(India), with notes on biology II(Suborder: Anisoptera), Oriental Insects, 7; 291- 331 (1973b).

20. Westfall M. J. and Tennessen K. J., Odonata, (Edited by Merrit, R. \& Cummins), In: An Introduction to the Aquatic Insects of North America, 3rd edn, Kendall-Hunt Publishing Co., Dubuque, IA, 164-211 (1996).

21. Chessman B. C., New sensitivity grades for Australian river macroinvertebrates, Marine and Freshwater Research, 54; 95-103 (2003).

22. Purkayastha P. and Gupta S., Estimating ecosystem health of shallow water pond in lower Irongmara, Barak Valley, Assam, India, using ASPT, SPI and BMWP score, International Research Journal of Biological Sciences, 2(8); 1-4 (2013).

23. Purkayastha P. and Gupta S., Ecology of Monabeel, a floodplain ecosystem of Cachar, Assam with special reference to aquatic insect community, Tropical Ecology, 56(2): 245-255 (2015).

24. Gooderum, J. and Tsyrlin, E., The Waterbug book, A guide to the Freshwater Macroinvertebrates of Temperate Australia. CSIRO Publishing, Collingwood Vic. (2002).

25. Mandaville, S.M., Benthic Macroinvertebrates in Freshwaters- Taxa Tolerance Values, Metrics, and Protocols. Project $\mathrm{H}-1$, Soil \& Water Conservation Society of Metro Halifax, (2002).

26. Hilsenhoff, W. L., Rapid field assessment of organic pollution with a family-level biotic index, J. N. Am. Benthol. Soc. 7(1): 65-68 (1988).

27. Mackie, G. L., Applied Aquatic Ecosystem
Concepts. Kendall/Hunt Publishing Company, ISBN: 0-7872-7490-9. xxvi, p-744 (2001).

28. Nasirian $\mathrm{H}$., Evaluation of water quality and organic pollution of Shadegan and Hawr Al Azim wetlands by biological indices using insects, JEZS, 2(5): 193-200 (2014).

29. Wenn C.L. Do freshwater macroinvertebrates reflect water quality improvements following the removal of point source pollution from Spen Beck, West Yorkshire? Earth \& E-nvironment, 3: 369-406 (2008).

30. Friedrich G., Chapman D., and Beim, A., The Use of Biological Material in Water Quality Assessments: A Guide to the Use of Biota, Sediments and Water in Environmental Monitoring, 2nd ed. (Edited by Deborah Chapman), E \& FN Spon, New York (1996).

31. Lenat D. R., A biotic index for the southeastern United States: derivation and list of tolerance values, with criteria for assigning water-quality ratings, J. N. Am. Benthol. Soc. 12; 279-290 (1993).

32. Blocksom K. A. and Winters L., The evaluation of methods for creating defensible, repeatable, objective and accurate tolerance values for aquatic taxa, EPA 600/R-06/045 (2006).

33. Alba-Tercedor J., Zamora-Munoz C., SanchezOrtega A. and Guisasola I., Mayflies and stone flies from the RioMonachil (Sierra, Nevada Spain) (Ephemeroptera and Plecoptera), (Edited by J. Alba- Tercedor \& A. Sanchez -Ortega), In: Overview and Strategies of Ephemeroptera and Plecoptera, Sand- Hill Crane Press Inc., p-529-538 (1991).

34. Gupta S. and Narzary R., Aquatic insect community of lake, Phulbari anuaof Cachar, Assam. J of Environmental Biol, 34(3); 591597 (2013). 